\title{
ZIVIANI, Giampietro, Una Chiesa di popolo. La parrochia nel Vaticano II. Bolonha: Dehoniane, 2011. 306p.
}

\author{
Rafael Martins Fernandes ${ }^{1}$
}

O autor, Giampietro Ziviani, falecido aos 51 anos de idade em 2014, foi um promissor eclesiólogo da Faculdade de Triveneto (Pádua, Itália). Ele escreveu esta obra com o objetivo de revisitar as afirmações do Concílio Vaticano II sobre a paróquia, mantendo vivo o debate sobre isso. Percorrendo as publicações teológicas dos últimos anos, Ziviani percebeu a existência de poucas reflexões teológicas sobre a paróquia. Em seguida, perturbou-o o parecer comum de que o Concílio praticamente ignorou a paróquia, concedendo-a um lugar marginal. Contudo, quando passou para a análise da prática pastoral, ele constatou que o déficit de reflexões teóricas não impediu a multiplicação de iniciativas de renovação, nas quais promoveu-se de modo um tanto superficial a eclesiologia de comunhão, sem aprofundamento do debate conciliar. Daí, compreende-se a justificativa do autor de "verificar melhor" o Vaticano II, "entendendo as motivações deste aparente desinteresse" (p. 28).

A título de introdução, também se deve dizer que este livro italiano, publicado em 2011, é desconhecido pelo público brasileiro. Mesmo que o público-alvo sejam as comunidades católicas europeias, a leitura desta obra no Brasil torna-se útil, porque a recuperação da temática conciliar toca em cheio os propósitos de renovação paroquial na América Latina.

A obra é orientada pelo método histórico-teológico e está dividida em quatro capítulos: Fazer teologia sobre o Vaticano II - a questão das fontes históricas (1); A paróquia na vigília do Concílio - os votos da fase ante preparatória (2); A paróquia durante o Concílio - gestos e textos conciliares (3); Uma Igreja em forma de povo (4). No seu conjunto, os capítulos são bem fundamentados em Atas e Documentos conciliares, em textos de Magistérios Pontifícios e em teólogos contemporâneos, como é demonstrado na bibliografia final que relaciona mais de 240 títulos de obras.

$\mathrm{Na}$ introdução, Ziviani situou a paróquia dentro de um "novo horizonte" cultural secularizado, no qual a concepção de ser humano foi modificada em relação à noção tradicional, que compreendia a pessoa estreitamente vinculada e submetida ao peso das 
instituições e tradições. Na nova paisagem religiosa, o indivíduo ocupa o centro, o que resulta no declínio das estruturas comunitárias e das culturas holísticas (p. 20 e 21). Citando o exemplo da Igreja italiana, o autor afirmou que a crise da instituição paroquial fez os bispos italianos insistirem na "vocação popular da paróquia", próxima às pessoas, com uma proposta personalizada que conduz à pastoral de sujeitos e de ambientes (p. 28 a 30).

O eclesiólogo italiano, no primeiro capítulo, interrompeu a reflexão introdutória sobre a paróquia, para dedicar-se à análise do uso das fontes históricas. Ele quis deixar claro aos seus leitores o modo como ele interpreta o Vaticano II, evitando uma simplificação interpretativa que "reduz a riqueza de uma 'epifania de Igreja' entre as mais altas a uma mecânica política de lutas" entre progressistas e conservadores (p. 41). Em seu ponto de vista, ele procurou interpretar o Concílio a partir de uma complementariedade entre história e teologia, o que lhe permitiu aproximar-se adequadamente dos textos conciliares sobre a paróquia (p. 60-62).

No segundo capítulo, o autor ateve-se, de modo breve, à análise das duas mil contribuições elaboradas na vigília do Concílio por bispos, provinciais de congregações religiosas e reitores de universidades vinculados à Igreja Católica. Ele sistematizou-as segundo as demandas paroquiais das Igrejas Particulares dos continentes europeu, asiático, africano e americano, com destaque para as Igrejas europeias. Tais contribuições oferecem uma visão de como era a consciência dos bispos e a situação eclesial do período. Em meio às peculiaridades de cada região, os principais problemas das paróquias resumem-se em: imobilidade dos párocos, o que resultava no isolamento dos mesmos em relação à diocese; isenção de obediência aos bispos por parte dos religiosos; uma concepção eclesiológica jurisdicista, centrada nas regras, sem muitas vezes se perguntar pelos princípios teológicos que deveriam orientar a vida pastoral (p. 118); concepção estática de paróquia, centralizada no pároco e pouco preocupada em realizar atividades missionárias. As possíveis soluções, de modo geral, visaram modificar alguns cânones do Código de Direito Canônico, mas não em mudar a paróquia a partir do seu interior (p. 125). Por exemplo, não se pensava ainda em aprofundar a teologia do Episcopado e da Igreja Particular que, por sua vez, ofereceriam elementos importantes para a implementação das reformas tão almejadas pelos próprios bispos.

No capítulo terceiro, o autor adentrou no evento conciliar chamando a atenção para as intervenções dos bispos e dos papas João XXIII e Paulo VI referentes à paróquia durante o período das aulas conciliares, seguido de uma análise dos diferentes textos aprovados que tratam sobre o tema paroquial. Vale a pena assinalar o destaque que o autor conferiu à mudança de perspectivas nos discursos entre a primeira e a segunda seções conciliares. Na primeira seção (1962-1963), a paróquia foi afirmada, em meio à raras menções, em seu caráter objetal, como uma estrutura na qual se colocam conteúdos e não como um conteúdo verdadeiro e próprio (p. 139 e 140). Na segunda seção (1963-1964), os padres foram realizando as suas primeiras sínteses teológicas sobre o tema. Assim, por exemplo, Dom Eduard Schick, representando os bispos alemães e escandinavos, inseriu o tema paroquial em seu discurso de valorização das Igrejas locais. Segundo ele, a paróquia "não é uma seção administrativa da Igreja, mas uma verdadeira imagem e manifestação da Igreja Universal" (p. 141). Delineava-se uma nova consciência mistérica, na qual a paróquia aparece como um sujeito vivo que manifesta o mistério da Igreja de Cristo em determinado local. Esta reflexão desenvolveu-se, de modo esparso, nas Constituições Sacrosantum Concilium e Lumen gentium, bem como nos Decretos Christus Dominus, Presbyterorum ordinis, Apostolicam Actuositatem e Ad gentes, tratados respectivamente pelo autor.

O fio condutor da reflexão conciliar sobre a paróquia é a imagem de Igreja como "sacramento". Nesse sentido, Ziviani salienta o uso de termos como "representar" e "tornar visível". Em um primeiro nível de sacramentalidade das paróquias, encontram-se as próprias comunidades paroquiais que, estruturadas na forma de povo, “'representam', de algum modo (quodammodo), a Igreja visível espalhada por todo o mundo" (SC 42). Tal visibilidade 
ocorre de forma privilegiada na assembleia eucarística. A expressão quodammodo aponta para a incompletude de representatividade da paróquia, pois ela é só uma célula da Igreja diocesana. É esta última que constitui, de modo perfeito, a imagem da Igreja Universal (p. 149). Em um segundo nível de sacramentalidade, está o ministério pastoral do pároco. Conforme $L G 28$, o pároco "torna visível” o Bispo diocesano - o sucessor dos Apóstolos - na comunidade de fiéis, e por isso, está habilitado para o exercício da função de pastor próprio na comunidade a ele confiada (p. 185). O autor destacou ainda que a recuperação das perspectivas mistérica e sacramental não está separada da noção hermenêutica de Igreja denominada "povo de Deus". A articulação da noção de "povo" dentro da teologia da paróquia torna-se fundamental para estipular a prioridade do aspecto comunitário sobre o princípio territorial e sobre os papéis específicos de autoridade que se desenvolvem no seu interior (p. 147 e 233). A conclusão parcial do autor foi que, mesmo que os textos conciliares sobre a paróquia tenham sido poucos e esparsos, estes são bons e inserem-se de modo harmônico no quadro maior de renovação eclesiológica do Vaticano II (p. 230 e 231).

No quarto capítulo, o autor descreveu, em largos passos, a trajetória das reflexões teológicas sobre a paróquia ocorridas no pós-concílio. Delinearam-se duas fases de recepção conciliar, com consequências para a compreensão da missão da comunidade paroquial. Na primeira fase, houve fortes mudanças na vida das paróquias, algo compreensível pelo fato de que estas se encontravam na encruzilhada de muitos temas trabalhados no Concílio, como a liturgia, os ministérios, a missão e o ecumenismo. A categoria de "povo de Deus" esteve em alta nas reflexões da época. Isto favoreceu um dinamismo mais participativo e missionário dos leigos em meio à crise que sobressaltou a Igreja no final dos anos sessenta e na década de setenta (p. 235 e 236). A segunda fase foi marcada pelo declínio do conceito "povo de Deus" e a assunção da categoria "mistério de comunhão". O evento que marcou esta transição foi o Sínodo Extraordinário de 1985. A justificativa apresentada por Ziviani para essa mudança foi, para além do uso equívoco do conceito "povo de Deus" do período, a crise interna da Igreja, situação que exigiu uma atenção maior da instituição eclesial sobre si mesma (p. 246). No entanto, o que o autor percebeu foi uma diminuição do interesse teórico pela figura da paróquia e uma apressada tendência em identificar a categoria "comunhão" com os movimentos eclesiais surgidos na década de 80 (p. 254). Na prática, a paróquia mantinha a sua função tradicional de celebração dos sacramentos, ao mesmo tempo em que devia fazer o esforço para integrar em sua pastoral os movimentos eclesiais, dotados de maior dinamismo apostólico nas cidades. Os escritos de São João Paulo II corroboraram esta visão de paróquia (p. 261 e 270).

Nesse apanhado histórico conciliar e pós-conciliar, o autor situou a paróquia no justo horizonte do mistério da Igreja e da história. Ele mostrou que as noções eclesiológicas "mistério de comunhão" e "povo de Deus" não podem ser colocadas em oposição, mas devem estar em harmonia, sendo articuladas pela categoria "sacramento", como bem fizeram os padres conciliares. Essas noções conciliares são fundamentais para manter vivo o "ideal comunitário" dos primeiros cristãos, evitando uma indesejável recaída da paróquia na mesma concepção administrativa precedente ao Vaticano II (p. 273).

No atual panorama europeu, afirmou o autor, é salutar que a noção "povo de Deus" retome aquela relevância que havia perdido na segunda fase da recepção conciliar (p. 271). Nesse sentido, "povo de Deus" torna-se útil para o entendimento da paróquia, pois ajuda a pensar as dinâmicas dessa instituição de forma mais concreta e histórica, repercutindo em uma maior valorização da Igreja local. De outra parte, essa noção popular também favorece a dilatação do conceito de pertença comunitária, desfazendo a impressão (falsa) de que a vivência qualificada da comunhão e da missão cristã nas cidades é algo que diz respeito 
sobretudo aos movimentos eclesiais. A paróquia popular é aberta "para todos", responsável por estabelecer vários graus de pertença e estilos de vida discipulares, desenvolvendo um protagonismo missionário no seu território (p. 277 e 278).

Enfim, afirma-se que a obra de Ziviani é um instrumento teórico qualificado de compreensão da renovação paroquial a partir do Concílio Vaticano II. Retornar às fontes conciliares da paróquia é um desafio salutar também para a teologia na América latina que, por sinal, tem novamente despertado para a reflexão teórica desse tema, como atesta a publicação do Documento da CNBB "Comunidade de comunidades: uma nova paróquia” (2014).

\section{REFERÊNCIAS}

Recebido: 16/09/2019

Aceito: 23/10/2019

Publicado: 29/12/2019

Endereco:

Rafael Martins Fernandes

Seminário Maior N. Sra. da Conceição, Av. Senador Salgado Filho, 7100, Bairro Jardim Lisboa, Viamão, RS, Brasil - CEP: $94440-000$

ACTA SYNODALIA SACROSANCTI CONCILII OECUMENICI VATICANI II. Cura et studio archivi concilii oecumenici Vaticani II. Volume II. Typis Polyglotis Vaticanis, 1970-2000. https://doi.org/10.21906/rbl.1446

CONCÍLIO ECUMÊNICO VATICANO II. Constituição Sacrosanctum concilium sobre a sagrada Liturgia (4.12.1963). São Paulo: Paulus, 1997.

CONCÍLIO ECUMÊNICO VATICANO II. Constituição Dogmática Lumen gentium sobre a Igreja (21.11.1964). São Paulo: Paulus, 1997.

NOCETI, Serena. Popolo di Dio nell'attuale dibattito ecclesiologico. Servitium, Milão, v. 41, n. 173, p. 81-85. 2007.

ZIVIANI, Giampietro. Una Chiesa di popolo. La parrochia nel Vaticano II. Bolonha: Dehoniane, 2011. 